ZOOLOGIA 31 (2): 105-113, April, 2014

http://dx.doi.org/10.1590/S1984-46702014000200001

\title{
What do humpback whales Megaptera novaeangliae (Cetartiodactyla: Balaenopteridae) pairs do after tagging?
}

\section{Artur Andriolo ${ }^{1,3,6}$, Alexandre N. Zerbini2,3, Sergio Moreira ${ }^{3,4}$, José L. Pizzorno ${ }^{3}$, Daniel Danilewicz ${ }^{3,5}$, Ygor G. Maia3 , Natália Mamede ${ }^{1,3}$, Franciele R. de Castro ${ }^{1,3}$ \& Phillip Clapham²}

\author{
${ }^{1}$ Departamento de Zoologia, Instituto de Ciências Biológicas, Universidade Federal de Juiz de Fora. Rua José Lourenço \\ Kelmer, São Pedro, 36036-900 Juiz de Fora, MG, Brazil. \\ ${ }^{2}$ National Marine Mammal Laboratory, Alaska Fisheries Science Center, NOAA Fisheries. 7600 Sand Point Way NE, Seattle, \\ WA, 98115, USA. \\ 3 Instituto Aqualie. Avenida Dr. Paulo Japiassu Coelho 714, Sala 206, Cascatinha, 36033-310 Juiz de Fora, MG, Brazil. \\ ${ }^{4}$ Laboratório de Bioacústica e Ecologia de Cetáceos, Departamento de Ciências Ambientais, Instituto de Florestas, Universidade \\ Federal Rural do Rio de Janeiro. Rodovia BR 465, km 7, 23890-000 Seropédica, RJ, Brazil. \\ ${ }^{5}$ Departamento de Ciências Biológicas, Universidade Estadual de Santa Cruz. Rodovia Ilhéus, Itabuna, km 16, \\ 45662-900 Ilhéus, BA, Brazil. \\ ${ }^{6}$ Corresponding author. E-mail: artur.andriolo@ufjf.edu.br
}

\begin{abstract}
The social structure of humpback whales in their tropical wintering grounds is very fluid. To date, no information has been published for cases in which two whales were both satellite-tagged while in association. Here, we report the movements of four humpback whale pairs tagged together off the coast of Brazil. Fieldwork and satellite tagging of humpback whales was conducted between 2003 and 2008 along the eastern coast of Brazil, between $20^{\circ} \mathrm{S}$ and $8^{\circ} \mathrm{S}$. Movement was monitored while whales were still in their breeding ground. A switching state space model was applied to the filtered data of each humpback whale to standardize telemetry data and allow direct comparison of each individual track. GIS was used to plot model-predicted locations and to visually compare animal movements. The results confirm the short-lived nature of associations between breeding humpback whales, and shows that individuals differ widely in their movements.
\end{abstract}

KEY WORDS. Cetacean; large whale; satellite telemetry; social behavior; SSSM.

Humpback whales, Megaptera novaeangliae (Borowski, 1781), occur in all major oceans of the world. They are one of the most well studied large whale species, but much remains unknown about their behavioral ecology. In the Southern Hemisphere the species typically migrates from summer feeding grounds in the Antarctic to mating and calving grounds in tropical and subtropical coastal waters (DAwBin 1956, Chittleborough 1965, Mackintosh 1965, Zerbini et al. 2006, 2011). Humpbacks move through ocean waters during migration (e.g., ZeRBinI et al. 2006), or during residency in feeding areas (e,g., Dalla Rosa et al. 2008).

The International Whaling Commission (IWC) afforded Humpback whales virtually complete protection in the mid 1960s, and currently recognizes seven humpback whale breeding grounds in the Southern Hemisphere with corresponding feeding areas in high-latitude Antarctic waters (IWC 1998, 2005). Breeding Stock 'A' (BSA) corresponds to whales wintering off Brazil. In this region, the species typically occur from the northern portion of the South America $\left(\sim 5^{\circ} \mathrm{S}\right)$ to Cabo Frio area $\left(\sim 23^{\circ} \mathrm{S}\right)$ in the state of Rio de Janeiro (ANDRIolo et al. 2010). Occasional records have been observed along the South American conti- nent and near oceanic islands (PINEDo 1985, Lodi 1994, Siciliano 1997, Pizzorno et al. 1998), but it is not yet clear whether these regions correspond to the regular range of the species.

An aerial survey conducted in 2005 constituted the first systematic effort to confirm that the southern limit of the breeding ground of Humpback whales on the continental shelf corresponded to the coast of Rio de Janeiro state $\left(\sim 23^{\circ} \mathrm{S}\right)$ (ANDrioLo et al. 2010). Results from this study were further supported by satellite telemetry (Zerbini et al. 2006). The Abrolhos Bank $\left(16^{\circ} 40^{\prime}\right.$ to $\left.19^{\circ} 30^{\prime} \mathrm{S}\right)$ corresponds to the main breeding habitat of the species in the western South Atlantic Ocean (Siciliano 1997, Martins et al. 2001, Morete et al. 2003, ANDriolo et al. 2006, 2010), with some individuals showing relatively high site-fidelity to this region (Wedekin et al. 2010). Humpback whales that reproduce off Brazil migrate to summer feeding grounds to the west of the South Scotia Sea, near the South Georgia and the South Sandwich Islands (Zerbini et al. 2006, 2011, Stevick et al. 2006, Engel \& Martin 2009). Animals that overwinter at the Abrolhos Bank may occasionally feed opportunistically in the waters of the western South Atlantic (DANILEWicz et al. 2009, Alves et al. 2009). 
The social structure of humpback whales in tropical waters is very fluid (Herman \& Antinoja 1977, Mobley \& Herman 1985, MatTila et al. 1989). With the exception of mothers and calves, long-term associations are relatively uncommon. The groups are usually small, but lager groups are formed in association with aggressive intrasexual competition among males (TYACK \& WHITEhead 1982, BaKes \& Herman 1984, Clapham et al. 1992). Observations of individuals in breeding ground suggest that humpbacks are not territorial (Tyack 1981, Clapham 2000). Stable associations between paired whales have been noted (CLAPHAM 2000), even among larger groups in feeding grounds (PERRY et al. 1990).

Humpback whales appear to be polygynous, with similarities to a lek mating system. Clapham (1996) has proposed the category of 'floating lek' for this species. Genetic analysis of paternity has shown that females mate with multiple males, at least from one year to the next (Clapham \& Palsboll 1997). Cypriano-Souza et al. (2010) found that individuals distributed along the Brazilian coast belong to a single population, without evidence of substructure (spatial or temporal differentiation).

Satellite tracking is an important tool to study the behavior and movements of marine mammals (e.g., Jouventin \& Weimerskirch 1990, Polovina et al. 2004) and has been applied to humpback whales, providing information on the habitat use, movements and migrations of individual whales (MATE et al. 1998, Zerbini et al. 2006, 2011, Dalla-Rosa et al. 2008, Mate \& BEST 2008). To date, however, there is no published information on the fate of individuals that were both satellite tagged while in association. Here, we report the movements of four pairs of humpback whales tagged together off the coast of Brazil.

\section{MATERIAL AND METHODS}

The breeding ground for humpback whales in this population was defined as the area within the continental shelf (depth $<200 \mathrm{~m}$ ) along the Brazilian coast between $5^{\circ} \mathrm{S}$ and $23^{\circ} \mathrm{S}$ (ANDRIolo et al. 2010). Fieldwork and satellite tagging of humpback whales was conducted between 2003 and 2008 along the northeastern coast of Brazil, between $20^{\circ} \mathrm{S}$ and $8^{\circ} \mathrm{S}$ (Fig. 1).

Daily searches for humpback whales were undertaken during good weather conditions (Beaufort sea state $\leqslant 3$ ) from a $10 \mathrm{~m}$ long fiberglass speedboat and two inflatable boats. Transmitter models and configurations differed among the survey years, but were basically the Wildlife Computers SPOT3, 4 and 5 housed in "mini-can" and "implantable" configurations (Table I). Deployment of the tags, biopsy sample collection followed the methods described by Heide-Jørgensen et al. (2006) and Zerbini et al. (2006).

Group categories were defined as follows (CLAPHAM 1993, Mattila et al. 1994, Clapham 2000): a) singleton - a lone individual (SIN); b) mother and calf pair (MOC) - for two individuals, being one adult and one individual less than half the size of the adult; c) mother and calf pair plus one escort (MOCE) - for a mother and calf pair (as defined above) plus one escort; d) pair - for two individuals; e) >pair, for three or more individuals.

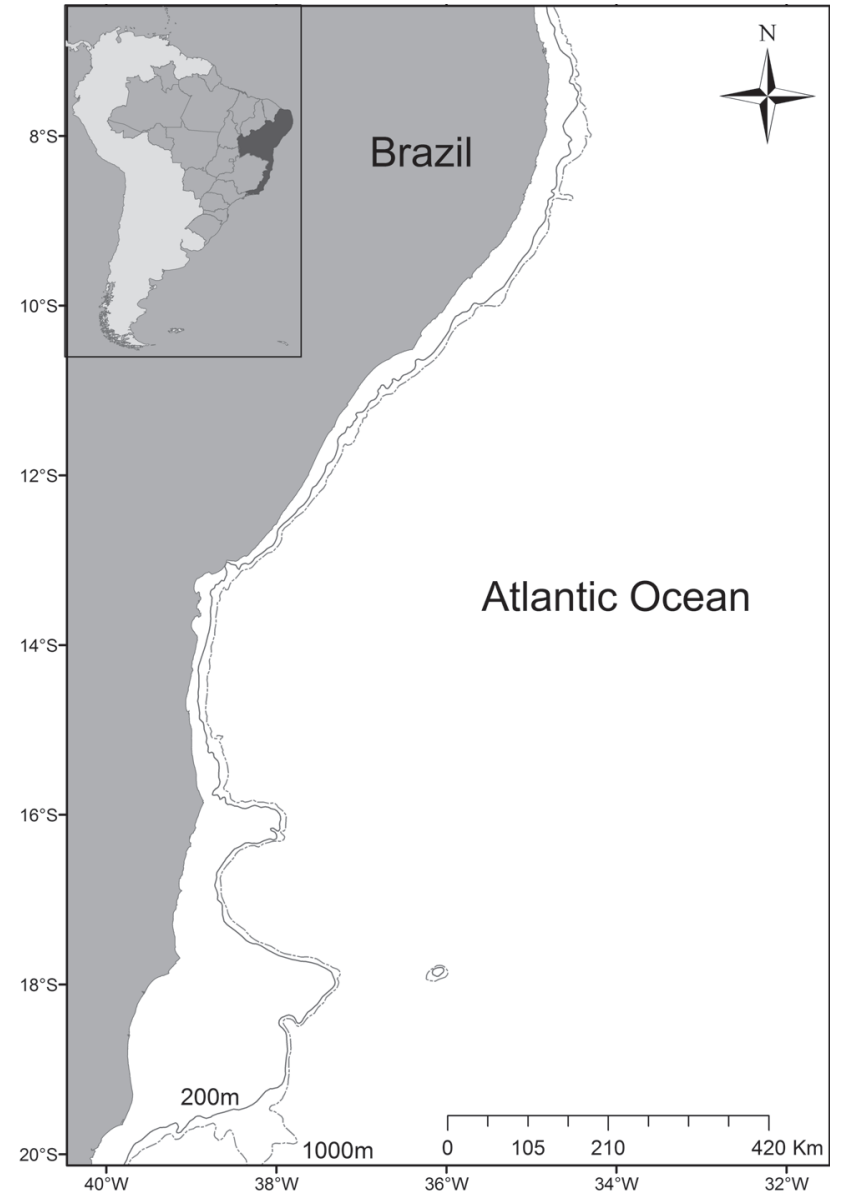

Figure 1. Northeastern coast off Brazil at breeding ground where humpback whales were satellite instrumented between 2003 and 2008. The light gray lines represent the 200 and $1000 \mathrm{~m}$ isobaths.

The social role of the tagged individuals were based on the position of the animal in the group composition: a) mother (MO); b) calf (C); c) escort (E) - a third whale accompanying a mother and calf, d) principal escort (PE) - whale closest to nuclear animal (MOC) in groups larger than three individuals and e) Other - animal with position not clearly identifiable. The group composition was defined at the moment of tagging. Groups with four different compositions were considered in this study: one competitive group (female and principal escort tagged), a mother with a female companion; a male-female pair, and another pair consisting of one male and one animal of unknown sex. Except for the latter animal, the sex of each individual was determined using methods described by BRuford et al. (1992) and Bérubé \& Palsbøll (1996). Table I summarizes information of the pairs considered in the analysis.

Movement was monitored after tag deployment while whales were still on the breeding grounds. Locations were obtained from Service Argos, Inc. (Argos 1990). Location quality 
(LC) of each tag transmission was coded A, B, 0, 1, 2 or 3 in increasing order of position accuracy. Argos locations were filtered considering an alternative algorithm, based on swimming speed, distance between successive locations, and turning angles (Freitas et al. 2008).

A switching-state space model (SSSM, Jonsen et al. 2005) was applied to the filtered data of each humpback whale individual. Modeling was conducted in open-source software packages, R (R Core Team 2011) and WinBugs (Lunn et al. 2000). The SSM allows location estimates to be inferred from observed data (satellite locations) by accounting for errors (measurement equation) and from dynamics of the movement process (transition equation) (PATTERSOn et al. 2008). Predicted locations were estimated at 6-hour time intervals. Although the SSSM provides the states, for this study we were interested only in the predicted latitude and longitude, in order to be able to compare both animals in each tagged pair. Because the time of the interpolated positions matched across all individuals, precise distances were computed for individuals within the pair. The speed of each animal was calculated as an average of the distances between two consecutive predicted locations divided by six hours. Animal tracks were plotted in a Geographic In- formation System (GIS) Package (ArcGIS 9) for visual inspection of animal movements. The Mann-Whitney Test was used to compare the speed between the two whales in the pair.

\section{RESULTS}

Between 2003 and 2008, four pairs of animals tagged while in association provided data to investigate the duration of their associations. The overall results of each pair are summarized in Table II. Except when associated with a mother and calf, males were on average faster than females (Table II).

Pair A consisted of a mother with a calf and an escort (MOCE). During the tagging period, two more individuals joined the group. The female was tagged first (21162) and the escort 55 minutes later (27259). Both tagged whales followed a similar track for five days (until October 24 $4^{\text {th }}$ ) (Fig. 2); then, on October $25^{\text {th }}$, the distance between them began to increase (Fig. 10). The male moved in a convoluted pattern, remaining in the same general area for seven days, while the female with the calf moved more linearly southwest along the continental shelf. The female traveled at a higher average speed than the male (Table II) $(\mathrm{U}=1288.00, \mathrm{p}=0.014)$.

Table I. Spatial and temporal data for humpback whale pairs A, B, C and D tagged on the Brazilian breeding grounds between 2003 and 2008. Year, tag number, transmitter type, sex, social role, group composition at the moment of deployment is presented for each pair.

\begin{tabular}{|c|c|c|c|c|c|c|c|c|c|}
\hline Pair & Year & Tag number & Transmitter type & Tagging date time & Latitude & Longitude & Sex & Social role & Group composition \\
\hline \multirow[t]{2}{*}{ A } & 2003 & 27259 & CAN & 10/19/2003 11:33 & -18.48 & -39.37 & $M$ & $\mathrm{PE}$ & $\mathrm{MOC}+\mathrm{PE}+2 \mathrm{O}$ \\
\hline & & 20162 & CAN & 10/19/2003 10:38 & -18.52 & -39.36 & $\mathrm{~F}$ & MO & $\mathrm{MOC}+\mathrm{PE}+2 \mathrm{O}$ \\
\hline \multirow[t]{2}{*}{ B } & 2007 & 37231 & IMP & 9/12/2007 10:32 & -17.98 & -39.09 & $\mathrm{~F}$ & MO & $\mathrm{MOC}+\mathrm{O}$ \\
\hline & & 27261 & IMP & 9/12/2007 10:51 & -17.98 & -39.08 & $\mathrm{~F}$ & $\mathrm{O}$ & $\mathrm{MOC}+\mathrm{O}$ \\
\hline \multirow[t]{2}{*}{ C } & 2008 & 87765 & IMP & $9 / 7 / 200813: 25$ & -10.74 & -36.51 & $\mathrm{~F}$ & MO & $\mathrm{MOC}+5 \mathrm{O}$ \\
\hline & & 87766 & IMP & 9/7/2008 13:41 & -10.73 & -36.53 & M & $\mathrm{O}$ & $\mathrm{MOC}+5 \mathrm{O}$ \\
\hline \multirow[t]{2}{*}{$\mathrm{D}$} & 2008 & 87761 & IMP & $8 / 28 / 200816: 10$ & -15.32 & -38.77 & M & $\mathrm{O}$ & Pair \\
\hline & & 87760 & IMP & $8 / 28 / 200814: 58$ & -15.36 & -38.76 & nd & $\mathrm{O}$ & Pair \\
\hline
\end{tabular}

(Nd) Not determined, (M) male, (F) female, (MOC) mother and calf pair, (MOCE) mother and calf pair plus one escort, (Pair) for two individuals, (E) escort, (PE) principal escort, $(\mathrm{O})$ other.

Table II. Satellite-monitored pairs of tagged humpback whales on the Brazilian breeding grounds between 2003 and 2008 . (ND) Not

\begin{tabular}{|c|c|c|c|c|c|c|c|c|c|c|}
\hline Pair & $\begin{array}{c}\text { Tag } \\
\text { number }\end{array}$ & Sex & $\begin{array}{c}\text { Argos } \\
\text { Positions }\end{array}$ & $\begin{array}{c}\text { SSSM } \\
\text { Positions }\end{array}$ & $\begin{array}{l}\text { Longevity } \\
\text { (days)* }^{*}\end{array}$ & $\begin{array}{c}\text { Distance } \\
\text { Monitored }(\mathrm{km})\end{array}$ & $\begin{array}{c}\text { Average speed } \\
(\mathrm{km} / \mathrm{h})\end{array}$ & $\begin{array}{l}\text { Pair Minimum } \\
\text { Distance }(\mathrm{km})\end{array}$ & $\begin{array}{c}\text { Pair Average } \\
\text { Distance }(\mathrm{km})\end{array}$ & $\begin{array}{c}\text { Pair Maximum } \\
\text { Distance }(\mathrm{km})\end{array}$ \\
\hline \multirow[t]{2}{*}{ A } & 27259 & Male & 51 & 60 & 14.5 & 848.46 & $2.39 \pm 2.13$ & 2.41 & 185.64 & 583.95 \\
\hline & 20162 & Female & 11 & & & 1026.23 & $2.89 \pm 1.62$ & & & \\
\hline \multirow[t]{2}{*}{ B } & 37231 & Female & 10 & 57 & 14.0 & 595.69 & $1.77 \pm 1.81$ & 3.59 & 61.69 & 154.43 \\
\hline & 27261 & Female & 41 & & & 399.98 & $1.19 \pm 1.79$ & & & \\
\hline \multirow[t]{2}{*}{$C$} & 87765 & Female & 263 & 82 & 20.3 & 1543.53 & $3.17 \pm 1.97$ & 1.63 & 100.49 & 214.27 \\
\hline & 87766 & Male & 88 & & & 1946.46 & $4.00 \pm 2.22$ & & & \\
\hline \multirow[t]{2}{*}{$\mathrm{D}$} & 87761 & Male & 203 & 123 & 30.5 & 3280.20 & $4.48 \pm 2.04$ & 0.20 & 260.52 & 727.50 \\
\hline & 87760 & ND & 258 & & & 3257.27 & $4.44 \pm 1.75$ & & & \\
\hline
\end{tabular}

* Longevity is the period in days that the pair was monitored. 

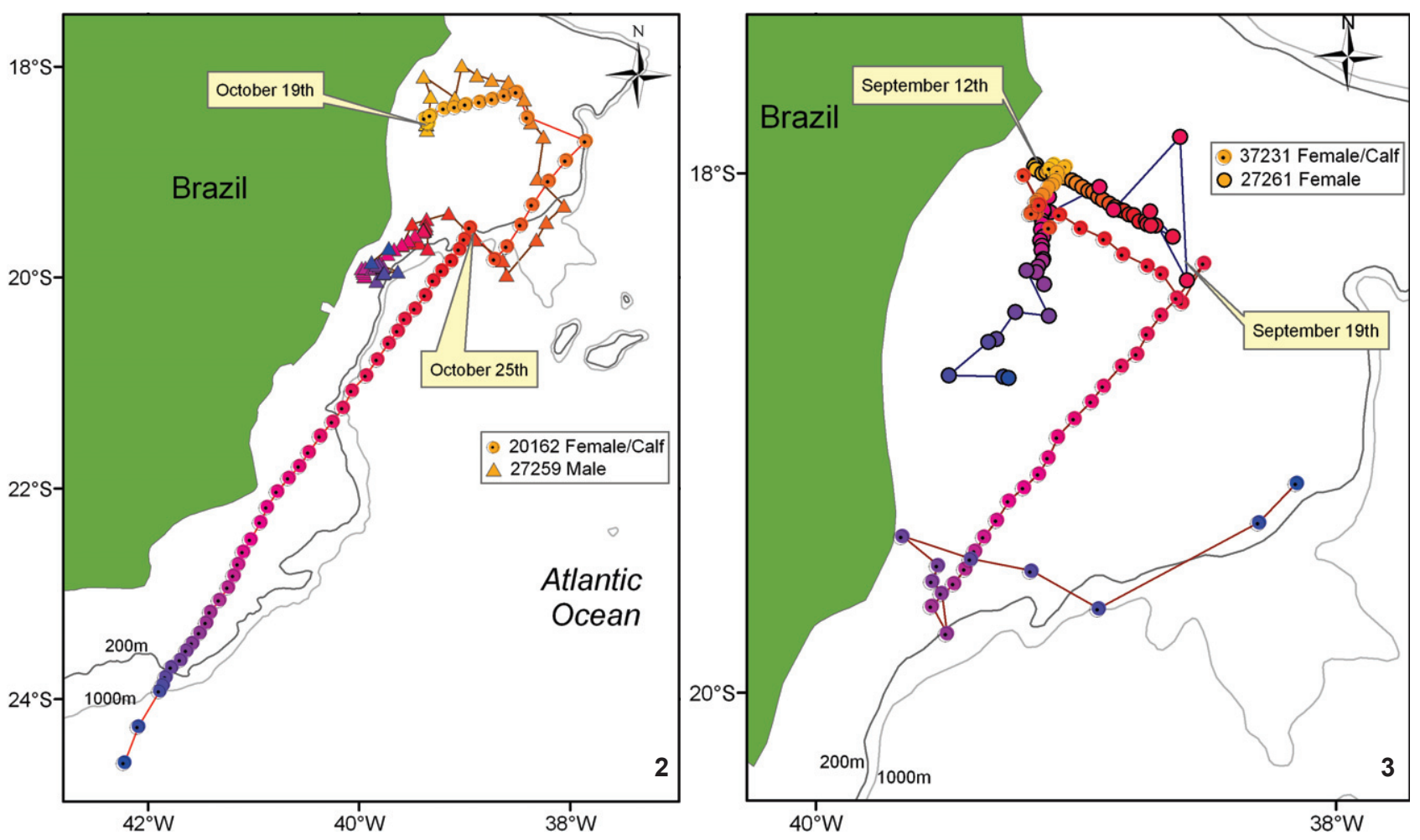

Figures 2-3. Movements of humpback whale Pairs A (2) and B (3), tagged on the Brazilian breeding grounds. The same colors correspond to the same dates for each individual.

The two members of Pair B, a mother (27261) with a calf and an adult (37231), identified as female by DNA analysis, were tagged 19 minutes apart. On September $19^{\text {th }}$, seven days after tagging, the distance between them began to increase (Figs 3 and 11). The mother with the calf moved slower (Table II) than the other female $(\mathrm{U}=3.49, \mathrm{p}<0.001)$.

Pair C, consisted of an adult male (87766) and an adult female (87765) (Fig. 4). Both were part of a group of six individuals, which included a calf. After tag deployment, the male moved north, while the female traveled in the opposite direction (towards the South) along the coast. At $125.3 \mathrm{~km}$ from the tagging position, the male turned back and headed south (Fig. 5). The female was at $175.1 \mathrm{~km}$ south of the tagging position on September $10^{\text {th }}$, when she turned north, swimming $51.7 \mathrm{~km}$; after this, she exhibited a convoluted movement beginning on September $11^{\text {th }}$ and ending on September $13^{\text {th }}$ when she headed south again (Fig. 5). At the same time, late on September $13^{\text {th }}$, the male was passing by the same area and at one point the two whales were within $1.9 \mathrm{~km}$ of each other (Fig. 12). On the next day, September $14^{\text {th }}$, the distance between them began to increase (Fig. 12). The male moved ahead; remarkably, the female followed the same track as the male, even where the continental shelf became larger. Close to the end of the monitored period, the male made a loop and con- tinued along the coast, while the female exhibited a more convoluted movement (Fig. 6). The male moved at a higher average speed than the female (Table II) $(\mathrm{U}=2508.00, \mathrm{p}=$ 0.009).

Pair D was composed of two adults, one male (87761) and another individual (87760) of unidentified sex (Fig. 7). The male headed north for $454.8 \mathrm{~km}$ and subsequently turned south on September $2^{\text {nd }}$ (Fig. 8). The other whale (87760) headed south after deployment (Fig. 8). On September $4^{\text {th }}$ they reached the greatest distance apart, $727.50 \mathrm{~km}$ (Fig. 13). At this moment both whales were on the southern portion of the continental shelf enlargement known as the Abrolhos Bank. Whale 87760 went further south along the coast and then on September $8^{\text {th }}$ made a turn and returned to the Abrolhos Bank, heading to the principal point from which humpback whales begin the migration to high-latitude feeding grounds. Whale 87761 crossed the Abrolhos Bank on its eastern side and initiated its southbound migration. On September $12^{\text {th }}$, after crossing the $500 \mathrm{~m}$ isobath, the predicted locations of the two whales were just $0.208 \mathrm{~km}$ apart (Fig. 13). Subsequently, whale 87760 swam southwards and male 87761 followed approximately the same track until the end of the monitoring period (Fig. 13. There was no difference in the average speed of the two whales (Table II) ( $\mathrm{U}=7561.0, \mathrm{p}=0.822)$. 

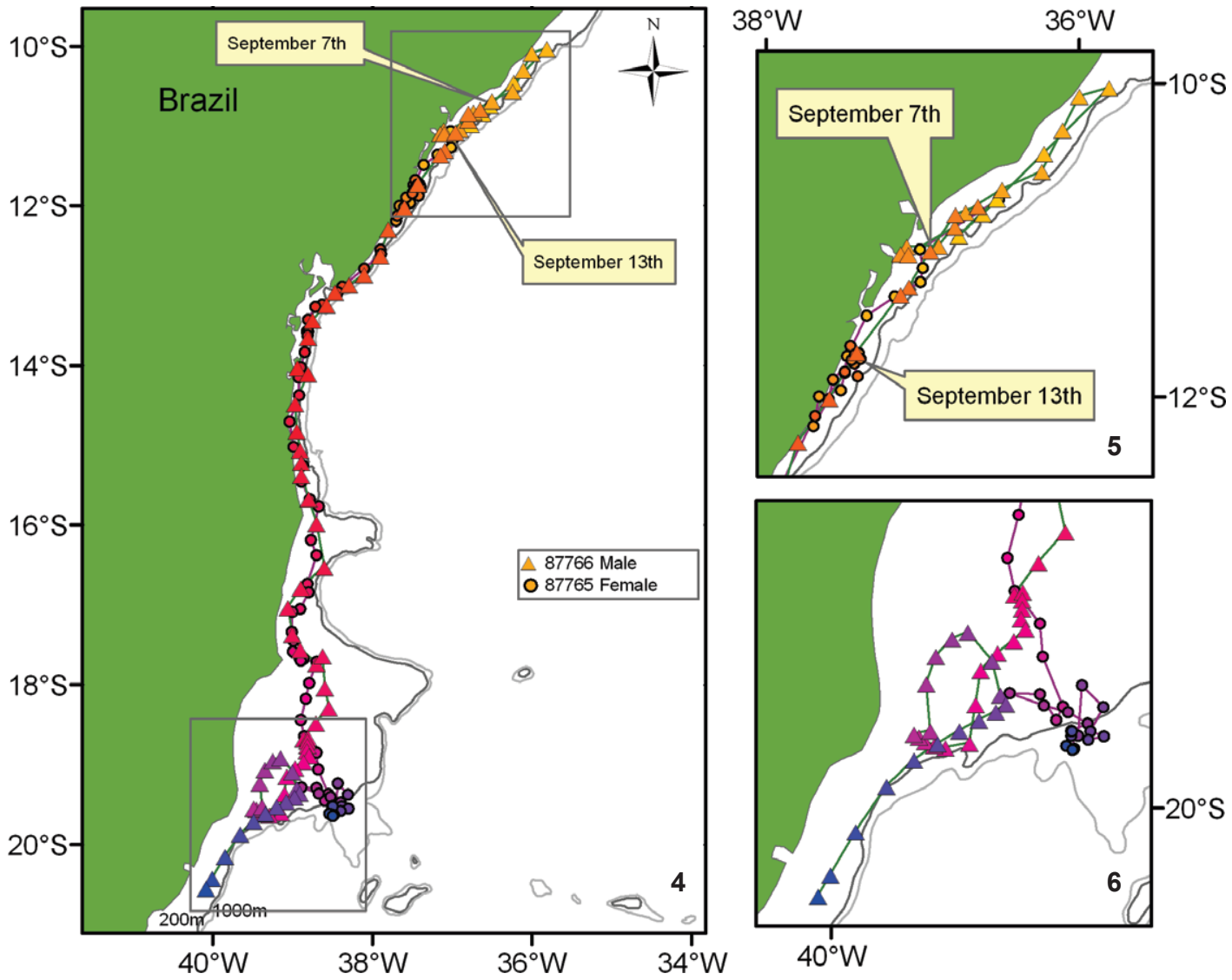

Figures 4-6. Movements of humpback whale Pair C tagged on the Brazilian breeding grounds: (4) overview of the tracks; (5) tracks after deployment; (6) shows the end of the monitoring period. The same colors correspond to the same dates for each individual.

\section{DISCUSSION}

The humpback whales tagged in association separated at different times after tagging and sometimes traveled in opposite directions. This study confirms reports in the general literature that humpback whale associations in the wintering (Herman \& Antinoja 1977, Mobley \& Herman 1985, Mattila et al. 1989, Clapham 1996) and feeding grounds (Weinrich \& Kulberg 1991) are ephemeral. However, there have been reports of stable social association in feeding grounds (WEINRICH 1991).

The social structure of mysticets is poorly understood due to the difficulties in identifying and defining the associations among individuals. While observations sometimes allow scientist to categorize these associations it is difficult to ascertain how long they last after the observations stop. We considered that pair A remained associated from the moment of tagging until October $24^{\text {th }}$ based on the distance between the two whales that did not increase significantly during that time. This would indicate that this pair remained in close proximity for at least 5 days. A similar pattern was observed for pairs B (length of association of four days) and D (length of association of one day).

The stable association between humpbacks at feeding areas has been classified as 'continuous' (individual whales associated for at least seven consecutive days) or 'recurring' (individuals associate at least five times within a 6-week period), although most groups were together for only brief periods (Weinrich 1991, Weinrich \& Kuhlberg 1991). Under this classification, the associations between the pairs monitored by us would not be considered stable, as the individuals were only together for brief periods.

The male of pair A was the escort of a female/calf pair. In this social role it was possibly waiting for mating opportunities (Clapham 1996), and it would be expected to stay with the female for as long as possible, until the female became receptive for mating, or until it found another female. The average speed of the female in this pair was higher than the male's.

Both individuals from pair D presented similar average speeds, which were higher than the speed of individuals in the other pairs. Whales moved linearly, a fact that reinforces the 

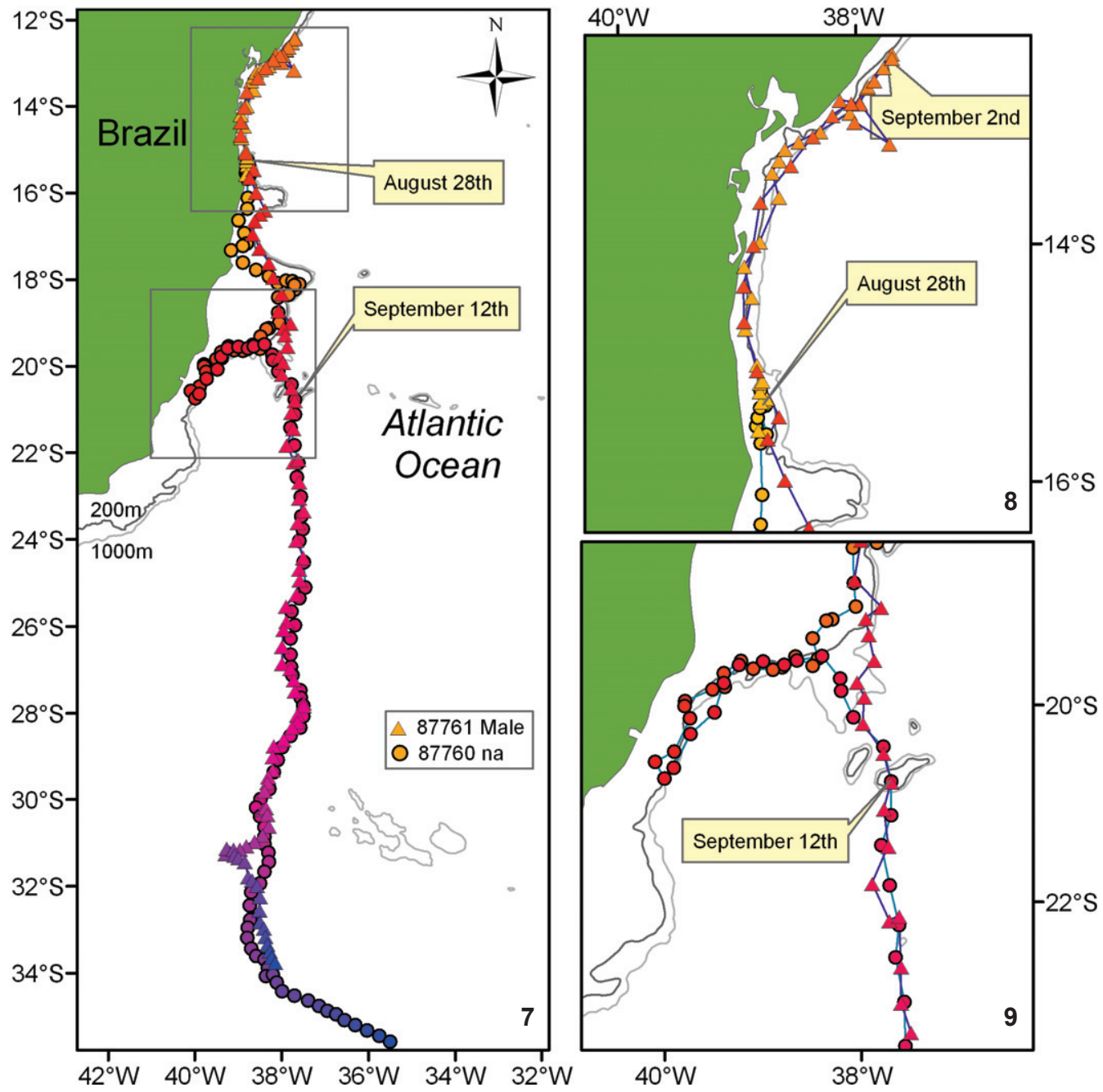

Figures 7-9. Movements of humpback whale Pair D tagged at the Brazilian breeding ground. (7) overview of the tracks; (8) tracks after deployment; (9) shows the end of the monitoring period. The same colors correspond to the same dates for each individual.

possibly that group D was composed of two males that were not competing for a mate. The movement pattern observed for this pair was not compatible with competition for mates. After being 15 days and $700 \mathrm{~km}$ far apart, it is notable that they approximated each other in the principal area where humpback whales begin the migration to high-latitude feeding grounds (ZeRBINI et al. 2006).

The social structure of humpback whales is very fluid in tropical waters (Herman \& Antinoja 1977, Mobley \& Herman 1985, Matrila et al. 1989). Despite the fluidity of the associations, the results indicate that whale associations on their breeding area are nonrandom. The pairs are not stable during the reproductive season, permitting females to join other males. In two cases (Pairs C and D), the tracks of tagged whales converged after being separated for periods of six and 15 days. Usual methods for behavioral studies (e.g., direct observation, photo identification and genetics) are based on an instantaneous sampling. Given the population sizes, the fluidity of groups and the distance between the individuals, such methodologies have a low probability of resighting the same individuals in association. Long-term satellite monitoring, however, may be able to locate possible reunions of previously associated whales.

The results presented here highlight two hypotheses that should be further investigated: 1) the whales recognize each other individually and 2) whales communicate far apart. In addition, our results are in accordance with the promiscuous mating in female Humpback whales (Clapham \& Palsboll 1997), confirm the short-lived nature of their breeding associations, and corroborate that individuals differ widely in their movements. 

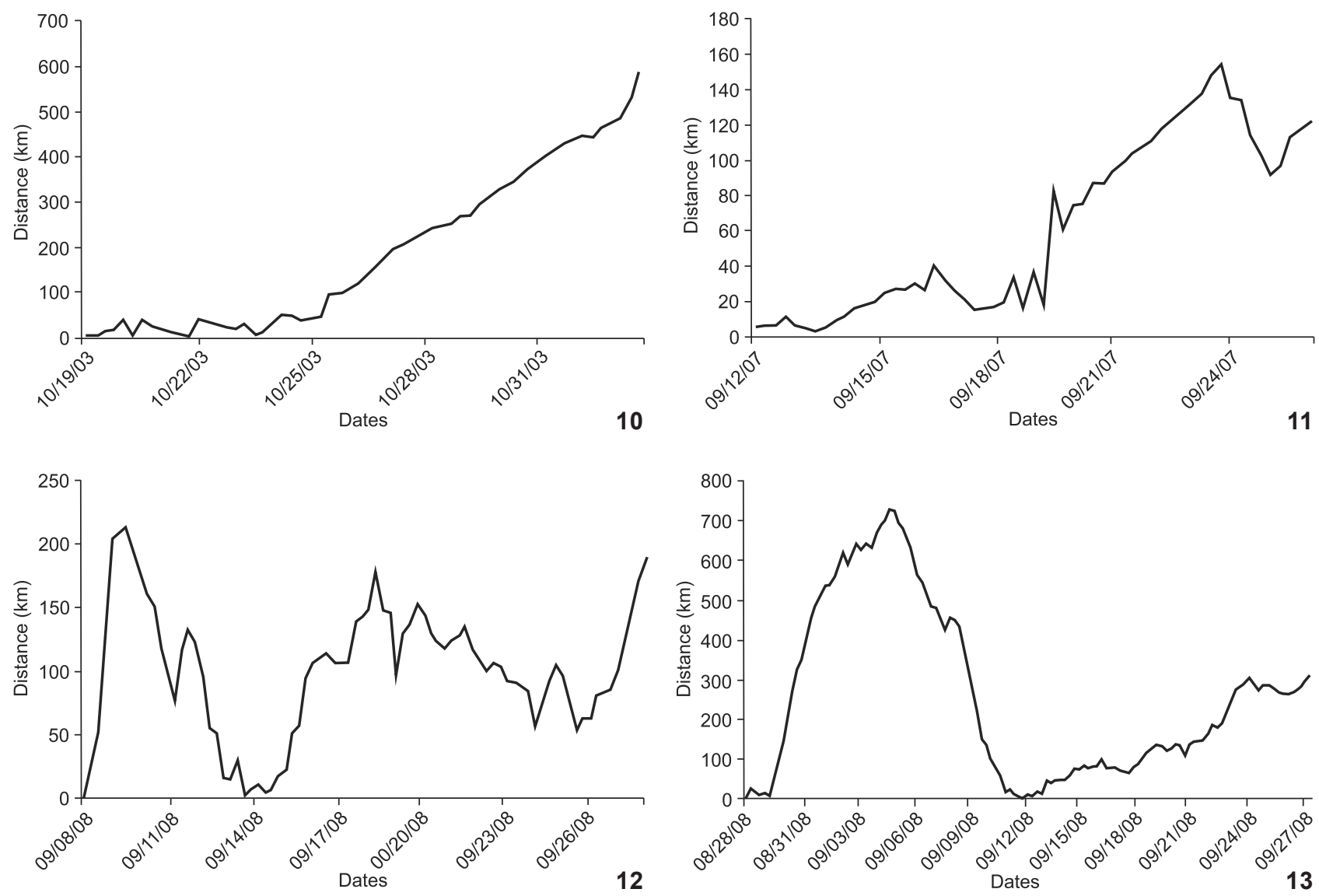

Figures 10-13. Calculated distance between the individuals humpback whales belonging to the same pair: (10) Pair A; (11) Pair B; (12) Pair C; (13) Pair D.

\section{ACKNOWLEDGEMENTS}

The Exploration and Production Division of Shell Brasil S.A have funded this study. We thank F. Caravello, P. Garcia and J. van den Dries for their interest in and support of the project. M.P. Heide-Jørgensen, M.V. Jensen, and A.V. Jensen professionally carried out tag deployment. Logistical and administrative support was provided by Biodinâmica Engenharia \& Meio Ambiente, the National Marine Mammal Laboratory (NMML) and the Washington Cooperative Fish and Wildlife Research Unit (WACFWRU), School of Aquatic and Fishery Sciences (SAFS), University of Washington (UW), Cascadia Research Collective and GEMARS. DNA extraction and gender determination were carried out by C. Miyaki and T. Matsumoto, Instituto de Biociências, Universidade de São Paulo, Brazil, and A.L. Cypriano de Souza, Pontifícia Universidade Católica do Rio Grande do Sul, Brazil. Assistance in the field was provided by P.C. SimõesLopes, G. VanBlaricon, L.C.P. de S. Alves, M.A.B. Crespo, M. de O. Dutra, M.C. de Lyra, E. Marone, J.V.A. Rocha, S. Moreira, S.M. Simão and the Atlantico Sul team in 2008. J. Waite, J. Ster- ling, M. Fergusson, and G. Schorr made suggestions and comments on the analysis and figures. A. Andriolo was post-doctorate at the National Marine Mammal Laboratory/NOAA supported by Brazilian Council for Scientific and Technological Development (CNPq, grant \#200619/2010-1 PDE). The Brazilian Council supported A.N.Z. for Scientific and Technological Development (CNPq, grant \#200.285/98-0), the Cetacean Assessment and Ecology Program NMML/AFSC/NMFS/NOAA, and the WACFWRU/SAFS/UW. This study was conducted under permits issued by CNPq (grant \#CMC 026/02-028/03) and the Brazilian Environmental Agency (IBAMA, permit \#009/02/CMA/ IBAMA, process \#02001.000085/02-27, ICMBio \#11523-1).

\section{LITERATURE CITED}

Alves, L.C.P.S.; A. Andriolo; A.N. Zerbini; J.L.A. Pizzorno \& P.J. Clapham. 2009. Record of feeding by humpback whales (Megaptera novaeangliae) in tropical waters off Brazil. Marine Mammal Science 25: 416-419. doi: 10.1111/j.17487692.2008.00249.x. 
Andriolo, A.;C.C.A. Martins; M.H. Engel; J.L. Pizzorno; S. MásRosa; A.C. Freitas; M.E. Morete \& P.G. Kinas. 2006. The first aerial survey to estimate abundance of humpback whales (Megaptera novaeangliae) in the breeding ground off Brazil (Breeding Stock A). Journal Cetacean Research and Management 8: 307-311.

Andriolo, A.; P.G. Kinas; M.H. Engel; C.C.A. Martins; \& A.M. RuFIno. 2010. Humpback whales within the Brazilian breeding ground: distribution and population size estimate. Endangered Species Research 11: 233-243. doi: 10.3354/ esr00282.

Argos. 1990. User's manual. Landover, Service Argos.

BaKer, C.S. \& L.M. Herman. 1984. Aggressive behavior between humpback whales (Megaptera novaeangliae) wintering in Hawaiian waters. Canadian Journal of Zoology 62: 19221937.

Bérubé, M. \& P. Palsbøll. 1996. Identification of sex in cetaceans by multiplexing with three Zfx and Zfy specific primers. Molecular Ecology 5: 283-287. doi: 10.1046/j.1365294X.1996.00072.x.

Bruford, M.W.; O. Hanotte; J.F.Y. Brookfield \& T. Burke. 1992. Single-locus and multilocus DNA fingerprinting, p. 225-269. In: A.R. Hoelzel (Ed.). Molecular Genetic Analysis of Populations. A Pratical Aproach. Oxford, IRL Press, XVIII+315p.

Chitleborough, R.G. 1965. Dynamics of two populations of humpback whale, Megaptera novaeangliae (Borowski). Australian Journal of Marine \& Freshwater Research 16: 33-128. doi:10.1071/MF9650033

Clapham, P.J. 1993. Social organization of humpback whales on a North Atlantic feeding ground. Symposium of the Zoological Society of London 66: 131-145.

Clapham, P. 1996. The social and reproductive biology of Humpback Whales: An ecological perspective. Mammal Review 26: 27-49. doi: 10.1111/j.1365-2907.1996.tb00145.x.

Clapham, P.J. 2000. The humpback whale. Seasonal feeding and breeding in a baleen whale, p.173-196. In: J. ManN; R.C. Connor; P.L. Tyack \& H. Whitehead (Eds). Cetacean Societies: Field Studies of Dolphins and Whales. Chicago, The University of Chicago Press, 433p.

Clapham, P.J. \& P.J. Palsboll. 1997. Molecular analysis of paternity shows promiscuous mating in female humpback whales (Megaptera novaeangliae, Borowski). Proceedings of the Royal Society $B$ 264: 95-98.

Clapham, P.J.; P.J. Palsboll; D.K. Mattila \& O. Vasquez. 1992. Composition and dynamics of humpback whale competitive groups in the West Indies. Behavior 122:182-194. doi: http:/ /dx.doi.org/10.1163/156853992X00507.

Cypriano-Souza, A.L.; G.P. Fernandez; C.A.V. Lima-Rosa; M.H. Engel \& S.L. BonatTo. 2010. Microsatellite genetic characterization of the humpback whale (Megaptera novaeangliae) breeding ground off Brazil (Breeding Stock A). Journal of Heredity 101: 189-200.
Dalla Rosa, L.; E.R. Secchi; Y.G. Maia; A.N. Zerbini \& M.P. HeideJorgensen. 2008. Movements of satellite-monitored humpback whales on their feeding ground along the Antarctic Peninsula. Polar Biology 31: 771-781. doi: 10.1007/s00300-008-0415-2.

Danilewicz, D.; M. Tavares; I.B. Moreno; P.H. Ott \& C.C. Trigo. 2009. Evidence of feeding by the humpback whale (Megaptera novaeangliae) in mid-latitude waters of the western South Atlantic. Marine Biodiversity Records 2 . doi:10.1017/S1755267209000943.

DawbIN, W.H. 1956. The migrations of humpback whales which pass the New Zealand coast. Transactions and Proceedings of the Royal Society of New Zealand 84: 147-196.

EnGEL, M.H. \& A.R. Martin. 2009. Feeding grounds of the western South Atlantic humpback whale population. Marine Mammal Science 25: 964-969. doi: 10.1111/j.17487692.2009.00301.x.

Freitas, C.; C. Lydersen; M.A. Fedak \& K.M. Kovacs. 2008. A simple new algorithm to filter marine mammal Argos locations. Marine Mammal Science 24: 315-325. doi: 10.1111/j.17487692.2007.00180.x.

Heide-Jørgensen, M.P.; J.M.V. Laidre; L. Dueck \& L.D. Postma. 2006. Dissolving stock discreteness with satellite tracking: Bowhead whales in Baffin Bay. Marine Mammal Science 22: 34-45. doi: 10.1111/j.1748-7692.2006.00004.x.

Herman, L.M. \& R.C. Antinoja. 1977. Humpback whales in the Hawaiian breeding waters: population and pod characteristics. The Scientific Reports of the Whales Research Institute Tokyo 29: 59-85.

International Whaling Commission (IWC). 1998. Annex G Report of the sub-committee on comprehensive assessment of Southern Hemisphere humpback whales. Report of the International Whaling Commission 48: 170-182.

InTERnATIONAL WhaLING Commission (IWC). 2005. Report of the subcommittee on other Southern Hemisphere whale stocks. Journal of Cetacean Research and Management 7: 235-253.

Jonsen, I.D.; J.M. Flemming \& R.A. Myers. 2005. Robust statespace modeling of animal movement data. Ecology 86: 2874-2880.

Jouventin, P. \& H. Weimerskirch. 1990. Satellite tracking of wandering albatrosses. Nature 343: 746-748. doi:10.1038/ $343746 \mathrm{a} 0$.

LodI, L. 1994. Ocorrências de baleias-jubarte, Megaptera novaeangliae, no Arquipélago de Fernando de Noronha, incluindo um resumo de registros de capturas no Nordeste do Brasil. Biotemas 7: 116-23.

Lunn, D.J.; A. Thomas; N. Best \& D. Spiegelhalter. 2000. WinBUGS - a Bayesian modelling framework: concepts, structure, and extensibility. Statistics and Computing 10: 325-337.

Mackintosh, N.A. 1965. The Stocks of Whales. London, Fishing News Books Ltd, 232p.

Martins, C.C.A.; M.E. Morete; M.H. Engel; A.C. Freitas; E.R. SECCHI \& P.G. KINAS. 2001. Aspects of habitat use patterns of 
humpback whales in the Abrolhos Bank, Brazil, breeding ground. Memoirs of the Queensland Museum 47: 563570.

Mate, B. \& P. Best. 2008. Coastal and offshore movements of southern right whales on the South African coast revealedby satellite telemetry. Reports of the International Whaling Commission SC/60/BRG8.

Mate, B.; R. Gisiner \& J. Mobley.1998. Local and migratory movements of Hawaiian humpback whales tracked by satellite telemetry. Canadian Journal of Zoology 76: 863-868.

Mattila, D.K.; P.J.Clapham; S.K. Katona \& G.S. Stone. 1989. Population composition of humpback whales, Megaptera novaeangliae, on silver bank, 1984. Canadian Journal of Zoology 67: 281-285.

Mattila, D.K.; P.J. Clapham; O.Vasquez \& R.S. Bowman. 1994. Occurrence, population composition, and habitat use of humpback whales in Samana Bay, Dominican Republic. Canadian Journal of Zoology 72: 1898-1907. doi: 10.1139/ z94-258.

Mobley, J.M. \& L.M. HeRman. 1985. Transience of social affiliations among humpback whales (Megaptera novaeangliae) in the Hawaiian wintering grounds. Canadian Journal of Zoology 63: 762-772. doi: 10.1139/z85-111.

Morete, M.E.; R.M. Pace; C.C.A. Martins; A. Freitas \& M.H. Engel. 2003. Indexing seasonal abundance of humpback whales around Abrolhos arquipelago, Bahia, Brazil. Latin American Journal of Aquatic Mammals 2: 21-28. doi:10.5597/ lajam00027.

Patterson, T.A.; L. Thomas; C. Wilcox; O. Ovaskainen \& J. Matthiopoulos. 2008. State-space models of individual animal movement. Trends in Ecology and Evolution 23: 8794. doi:10.1016/j.tree.2007.10.009.

Perry, A.; C.S. Baker \& L.M. Herman. 1990. Population characteristics of individually identified humpback whales in the central and eastern North Pacific: A summary and critique. Reports of the International Whaling Commission 12: 307-317.

Pinedo, M.C. 1985. A note on a stranding of the humpback whale on the southern coast of Brazil. The Scientific Reports of the Whales Research Institute 36: 165-168.

Pizzorno, J.L.A.; J. Lailson-Brito; P.R. Dorneles; A.F. Azevedo \& I.M.G.N. GurgeL. 1998. Review of strandings and additional information on humpback whales, Megaptera novaeangliae, in Rio de Janeiro, southeastern Brazilian coast (1981-1997). Report of the International Whaling Commission 48: 443-446.

Polovina, J.J.; G.H. Balazs; E.A. Howell; D.M. Parker; M.P. Seki \& P.H. Dutton. 2004. Forage and migration habitat of loggerhead (Caretta caretta) and olive ridley (Lepidochelys olivacea) sea turtles in the central North Pacific Ocean. Fisheries Oceanography 13: 36-51.

R Development Core Team. 2011. R: A language and environment for statistical computing. Vienna, R Foundation for Statistical Computing, ISBN 3-900051-07-0, available online at: http://www.R-project.org

Siciliano, S. 1997. Características da população de baleiasjubarte (Megaptera novaeangliae) da costa brasileira, com especial referência aos Bancos de Abrolhos. Rio de Janeiro, Universidade Federal Rural do Rio de Janeiro, 113p.

Stevick, P. T.; L.P. Godoy; M. Mcosker; M.H. Engel \& J. Allen. 2006. Movement of a humpback whale from Abrolhos Bank, Brazil to South Georgia. Journal of Cetacean Research and Management 8: 297-300.

TYACK, P. 1981. Interactions between singing Hawaiian humpback whales and conspecifics nearby. Behavioral Ecology and Sociobiology 8: 105-116. doi: 10.1007/ BF00300822.

TYACK, P. \& H. Whitehead. 1982. Male competition in large groups of wintering humpback whales. Behaviour 83: 1-23. doi: http://dx.doi.org/10.1163/156853982X00067.

Wedekin, L.L.; M.C. Neves; M.C.C. Marcondes; C. Baracho; M.R. Rossi-SANTOS; M.H. ENGEL \& P.C. SimÕES-LoPEs. 2010. Site fidelity and movements of humpback whales (Megaptera novaeangliae) on the Brazilian breeding ground, southwestern Atlantic. Marine Mammal Scince 26: 787-802. doi: 10.1111/J.17487692.2010.00387.x.

WEINRICH, M.T. 1991. Long term stability in grouping patterns of humpback whales (Megaptera novaeangliae) in the southern Gulf of Maine. Canadian Jourmal of Zoology 69: 3012-3019. doi: 10.1139/z91-425.

Weinrich, M.T. \& A.K. Kuhlberg. 1991. Short-term association patterns of humpback whale (Megaptera novaeangliae) groups on their feeding ground in the southern Gulf of Maine. Canadian Jourmal of Zoology 69: 3005-3011. doi: 10.1139/ z91-424.

Zerbini, A.N.; A. Andriolo; M.P. Heide-Jorgensen; J.L. Pizzorno; Y. Geyer; G.R. Vanblaricom \& D.P. Demaster. 2006. Satellitemonitored movements of humpback whales (Megaptera novaeangliae) in the Southwest Atlantic Ocean. Marine Ecology Progress Series 313: 295-304.

Zerbini, A.N.; A. Andriolo; M.P. Heide-Jorgensen; S. Moreira; J.L. Pizzorno; Y.G. Maia; G.Vanblaricom \& D.P. Demaster. 2011. Migration and summer destinations of humpback whales (Megaptera novaeangliae) in the western South Atlantic Ocean. Journal of Cetacean Research and Management 3: 113-118.

Submitted: 23.VIII.2013; Accepted: 14.XI.2013.

Editorial responsibility: Paulo da Cunha Lana 